\title{
Status of water pollution in the coalmine of Basundhara block, Ib valley, Orissa, India
}

\author{
*K. N. Singh and R. K. Singh \\ School of Studies in Geology, Vikram University, \\ Ujjain - 456010 (MP), India \\ (*Email: singhkn_vikram@yahoo.com)
}

\begin{abstract}
Water pollution in coalmines has become a serious concern of everyone and with the growing demand of energy, the quest for more coal exploitation has increased. The Basundhara block of Ib valley, Orissa, India, is an opencast mine at its developing stage. Looking into the state of its progress, the coalmine water quality and its impact on organisms are discussed in this study. To reduce the health hazard from coalmine waters, necessary plant species as accumulators or absorbents are suggested in this paper.
\end{abstract}

\section{INTRODUCTION}

Water pollution is basically defined as the addition of something to water, which changes its natural qualities (Coulsen and Forbes 1952). Water can be polluted by various agencies. Generally, some minerals are dissolved in water, as it comes into contact with various rocks. The quantity of dissolved minerals and chemical as well as biological characteristics of water determine its usefulness for various purposes. The presence of some minerals beyond certain limits affects its suitability for irrigational, domestic, or industrial usage.

Owing to coal mining and its subsequent utilisation, air and water are polluted in many ways and they lead to health hazards. The water of ponds and rivers is polluted due to the discharge of ash or coal fines from power stations or washeries. Such waters contain a significant amount of dissolved solids, suspended solids, some oil and ammonia (Singh and Singh 2000). Frequently, they are turbid and contain the dissolved solids beyond the permissible limits for drinking purposes.

\section{STUDYAREA}

The study area of Ib valley coalfield is situated in the northeast- to southwest-trending basin of the Son-Mahanadi valley. The name Ib valley was taken from the Ib River, a tributary of the Mahanadi River. The Basundhara River also drains the area as a second-order tributary of the Ib River. The study area is located between the north latitude $21^{\circ} 55^{\prime}$ and $22^{\circ} 05^{\prime}$, and east longitude $83^{\circ} 35^{\prime}$ and $83^{\circ} 45^{\prime}$ (Survey of India topographic map nos. $64 \mathrm{O} / 9$ and $64 \mathrm{~N} / 12$ ).

\section{METHODOLOGY}

Water samples were collected from 8 locations. Their $\mathrm{pH}$ was measured with an electronic $\mathrm{pH}$ meter (Systronics Digital $\mathrm{pH}$ meter, India). The value of chemical oxygen demand (COD) was determined by a fused reflex chamber-titrometric method. The value of biochemical oxygen demand (BOD) was obtained by measuring $\mathrm{O}_{2}$ concentration in samples before and after incubation in dark at $20^{\circ} \mathrm{C}$ for 5 days. $\mathrm{Na}^{+}, \mathrm{K}^{+}$, and $\mathrm{Ca}^{2+}$ were determined using a flame emission spectrophotometer. Total dissolved solids (TDS), total suspended solids (TSS), and total solids (TS) were measured by evaporating the water samples.

\section{RESULTS}

pH

It yields valuable data with regards to free $\mathrm{CO}_{2}$ and alkalinity. It is related to the metabolic activity of living organisms. Each organism has its optimum as well as tolerance range of $\mathrm{pH}$ value. Such tolerance values are given by WHO (1993) and Indian Standard Value (ISI 1983). A high concentration of $\mathrm{pH}$ is also toxic to the aquatic life. The water with a high $\mathrm{pH}$ after reacting with the natural alkaline water increases the carbonate hardness, and thus renders it unfit for its use in a laundry or a boiler. In the present investigation, the $\mathrm{pH}$ value ranges from 6.8 to 9.0. This is slightly higher than the WHO norms.

\section{COD}

The concentration of organic compounds in water can be estimated by their oxidability by oxidising substances 
Table 1: Status of water quality in the Basundhara area

\begin{tabular}{|c|c|c|c|c|c|c|c|c|c|c|c|}
\hline \multirow{2}{*}{ Parameters } & \multicolumn{8}{|c|}{ Sample No. } & \multirow{2}{*}{$\begin{array}{c}\text { WHO (1993) } \\
(\mathrm{Mg} / \mathrm{l})\end{array}$} & \multirow{2}{*}{ ISI (1983) } & \multirow{2}{*}{$\begin{array}{l}\text { ICMR } \\
(1975)\end{array}$} \\
\hline & 1 & 2 & 3 & 4 & 5 & 6 & 7 & 8 & & & \\
\hline $\mathrm{p}^{\mathrm{H}}$ & 8.9 & 9.0 & 7.9 & 8.0. & 6.8 & 6.7 & 8.8 & 8.7 & $6.5-8.5$ & $6.5-9.2$ & \\
\hline $\mathrm{COD}$ & 180 & 160 & 90 & 100 & 540 & 510 & 120 & 145 & & & \\
\hline BOD & 19 & 21 & 25 & 23 & 26 & 29 & 32 & 28 & & & \\
\hline TDS & 280 & 300 & 560 & 500 & 80 & 90 & 96 & 100 & $500-1500$ & $500-800$ & $500-1500$ \\
\hline TSS & 340 & 400 & 340 & 320 & 340 & 360 & 220 & 250 & $<100$ & & \\
\hline TS & 620 & 700 & 900 & 820 & 420 & 450 & 320 & 350 & $500-1500$ & $500-800$ & \\
\hline $\mathrm{K}^{+}$ & 2.3 & 2.7 & 1.0 & 1.3 & 1.0 & 1.2 & 1.1 & 1.4 & & & \\
\hline $\mathrm{Na}^{+}$ & 19.0 & 17.6 & 13.6 & 13.0 & 11.2 & 11.8 & 8.0 & 8.5 & 200 & & \\
\hline $\mathrm{Ca}^{+}$ & 0.38 & 0.59 & 0.77 & 0.68 & 0.38 & 0.45 & 0.38 & 0.65 & 200 & 200 & $75-200$ \\
\hline
\end{tabular}

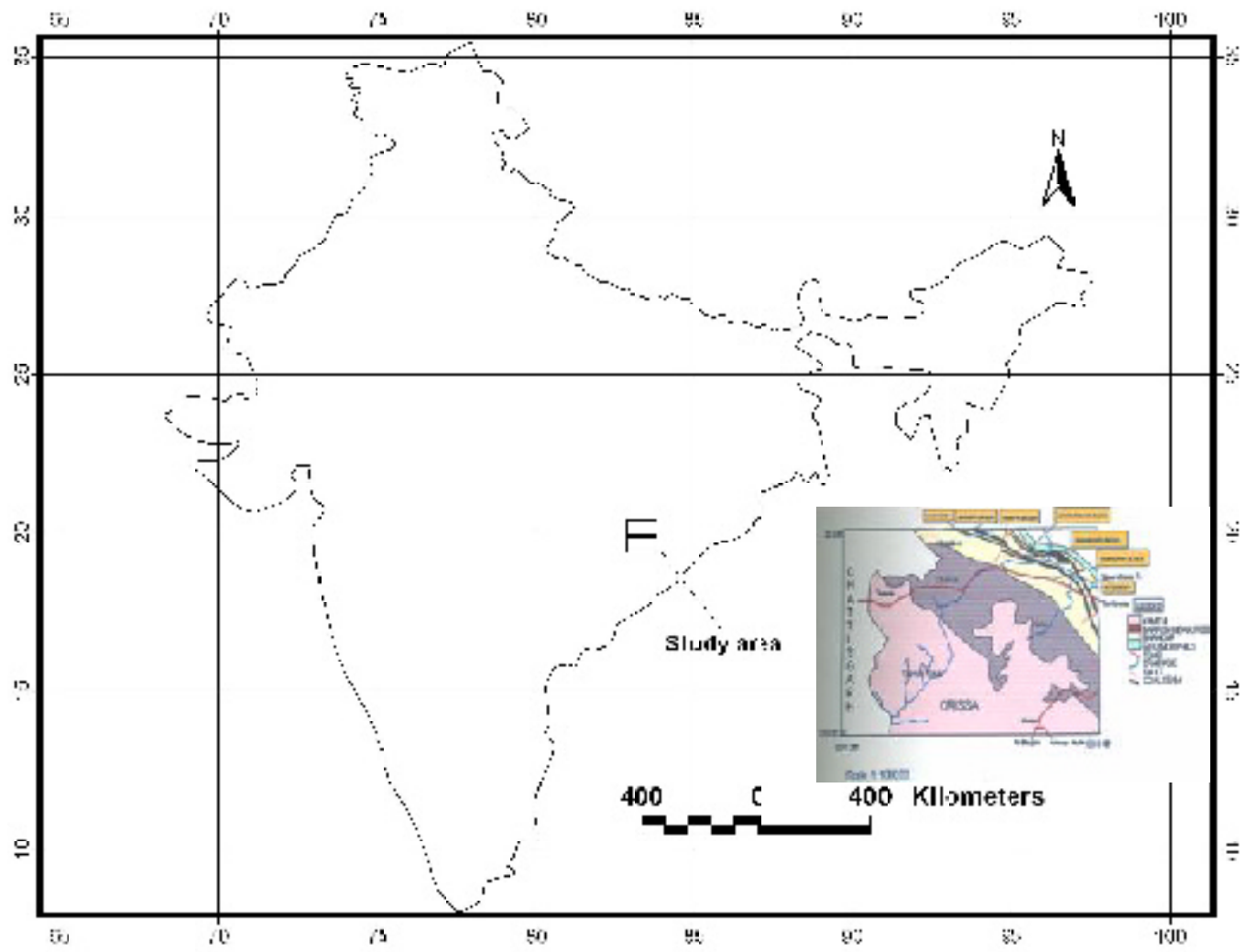

Fig. 1: Location map of the study area

such as $\mathrm{K}_{2} \mathrm{Cr}_{2} \mathrm{O}_{7}$. COD is related to the organic pollutant, which causes several health problems in the living organism. Each organism has its optimal and tolerance range of COD. The COD value of the water from different sampling locations ranges from 90 to $540 \mathrm{mg} / \mathrm{l}$. Like toxic chemicals, a higher concentration of COD in water creates unfavourable conditions for the growth of micro-organism.

\section{BOD}

The rate of removal of oxygen by micro-organisms using the organic matter present in water is called BOD. It indicates the presence of pathogenic bacteria. These bacteria were present in the intestines of humans and other warm-blooded animals, and were transmitted through faecal excreta. In the study area, BOD ranges from 19 to $32 \mathrm{mg} / \mathrm{l}$.

\section{TDS and TSS}

A high concentration of dissolved solids increases the density of water, which affects the osmoregulation of freshwater organisms and reduces solubility of gases (like oxygen). It also reduces the utility of water for drinking and other purposes. In the study area, TDS range from 80 to 560 $\mathrm{mg} / \mathrm{l}$. This value is below the recommended limit of WHO, ISI, and ICMR. In the study area TSS range from 220 to 400 $\mathrm{mg} / \mathrm{l}$. This is higher than the permissible limit of WHO (1993).

\section{TS}

TS were determined simply by weighing the material remaining after evaporation of a water sample (Rao 1993).A higher value of TS (due to a higher concentration of organic constituents) is responsible for affecting the taste and colour 
Table 2: Plant indicators of pollution level (After Liebman, 1962)

\begin{tabular}{c|c|c}
\hline $\begin{array}{c}\text { Oligosaprobic } \\
\text { Organisms }\end{array}$ & $\begin{array}{c}\text { Mesosaprobic } \\
\text { Organisms }\end{array}$ & $\begin{array}{c}\text { Polysaprobic } \\
\text { Organisms }\end{array}$ \\
\hline Cyclotella $\mathrm{sp}$. & Oscillatoria $\mathrm{sp}$. & Socillatoria $\mathrm{sp}$. \\
\hline Synedra sp. & Nitzchia sp. & Spirulilna $\mathrm{sp}$. \\
\hline Micrasterias $\mathrm{sp}$. & $\begin{array}{c}\text { Stephanodiscus } \\
\text { sp. }\end{array}$ & Euglena $\mathrm{sp}$. \\
\hline Surirella $\mathrm{sp}$. & Uronema $\mathrm{sp}$. & \\
\hline Tabellaria $\mathrm{sp}$. & Closterium $\mathrm{sp}$. & \\
\hline Bulbochaete $\mathrm{sp}$. & Asterionella $\mathrm{sp}$. & \\
\hline Ulothrix $\mathrm{sp}$. & Melosira $\mathrm{sp}$. & \\
\hline Cladophora $\mathrm{sp}$. & Scenedesmus $\mathrm{sp}$. & \\
\hline Euastrum $\mathrm{sp}$. & Tabelloria $\mathrm{sp}$. & \\
\hline Straurastrum $\mathrm{sp}$. & Tabelloria $\mathrm{sp}$. & \\
\hline Batrachospermum $\mathrm{sp}$. & Spirogyra $\mathrm{sp}$. & \\
\hline & Cladophora $\mathrm{sp}$. & \\
\hline
\end{tabular}

of water as well as adding odour and gas in it. The value of TS in the study area varies from 320 to $900 \mathrm{mg} / \mathrm{l}$. This is slightly higher than the ISI norm.

\section{$\mathbf{K}^{+}$}

Potassium is an important alkali metal found in water after Sodium. Potassium is the essential nutrient for both plant and animal life. It plays an important role in the metabolism of fresh water environment and is regarded to be an important macro-nutrient. The silicate minerals are the common source of potassium. The concentration of potassium in the study area ranges from 1.0 to $2.7 \mathrm{mg} / \mathrm{l}$.

\section{$\mathrm{Na}^{+}$}

Sodium is the most important alkali metal in natural waters. Nearly all sodium compounds are readily soluble and the concentration of sodium varies depending upon the origin of the water. The change in sodium has a direct impact on the alkalinity of water. If sodium content increases in the form of chloride and sulphate, it makes water salty, and the water is unfit for human consumption. High sodium content in irrigation waters brings about puddling of soils owing to a reduced water intake. In such soils, seed germination becomes difficult, as they become hard (Chhatwal 1997). In the study area, the concentration of sodium ranges from 8.0 to $19.0 \mathrm{mg} / \mathrm{l}$.

\section{$\mathrm{Ca}^{+}$}

Calcium is another important alkali metal found in water. Calcium along with magnesium ions is responsible for water hardness. Calcium is much more prevalent in the water of a region with deposits of limestone, dolomite, and gypsum. The hard water is not suitable for washeries and laundries. It affects the germination of seeds. The concentration of calcium in study area ranges from 0.38 to $0.77 \mathrm{mg} / \mathrm{l}$.

\section{Plants as indictors of pollution level}

The adverse effects of mining activities and pollutants on the environment can be assessed by studying the plants of that area. The following plants are the indicators of water pollution levels as oligosaprobic (scarcely polluted), mesosaprobic (moderately to highly polluted), and polysaprobic (extremely polluted) organisms.

Apart from this, a few plants have the capacity of metal accumulation in their leaves, stems, and roots.

\section{Plants as pollution controllers}

The following plants are efficient for treatment of $\mathrm{NH}_{4} \mathrm{~N}$ and the removal of TSS (78\% removal), BOD and phosphorous $(58-65 \%)$, and $\mathrm{NO}_{3} \mathrm{~N}(2-38 \%$ through poor dentrification).
1. Sebentine accuminater
2. Water hyacinth
3. Typha sp.
4. Schoenoplectus sp.
5. Myriophyllum sp.
6. Phragmites karka
7. Potamogeton pectinatus
8. Polygonum glabrum
9. Typha angurlata
10. Typha eleohantina

\section{CONCLUSIONS}

In the Basundhara block of Ib valley, the $\mathrm{pH}$ value of the coalmine waterranges from 6.8 to 9.0. This is slightly higher than the WHO norms. The COD value of the water ranges from 90 to $540 \mathrm{mg} / \mathrm{l}$, whereas BOD ranges from 19 to $32 \mathrm{mg} / \mathrm{l}$. The value of TSS lies between 220 and $400 \mathrm{mg} / \mathrm{l}$., which is significantly higher than the WHO limit of $<100 \mathrm{mg} / \mathrm{l}$.

There are a number of plant species that can be used as the indicators of water pollution level. Some of them can also be used for controlling pollution through their leaves, stems, and roots by the processes of adsorption, ion exchange, volatilisation, nitrification, and denitrification.

\section{ACKNOWLEDGEMENTS}

We thank Professor Pramendra Dev, Head School of Studies in Geology Vikram University, Ujjain, for providing necessary facilities. The sincere thanks are also due to Dr. Uma Sharma, School of Studies in Chemistry, Dr. S Srivastava, School of Studies in Zoology and Professor and Head Dr. V. P. Singh, Institute of Environment Management \& Plant Sciences, Vikram University, Ujjain for providing help during lab work. The help rendered by General Manager (HRD), Mahanadi Coalfield Limited, Sambalpur, Orissa and General Manager, Basundhara block, Ib-Valley Coalfield, 
Orissa is also thankfully acknowledged for providing necessary facilities in collecting the sample. The authors express their thankfulness towards University Grant Commission, New Delhi for Financial support. Thanks are also due to Mr. S. K. Dhanoria, Mr. Ashutosh Dixit and Mr. Awadhesh Bhatt for the assistance in the formatting the text.

\section{REFERENCES}

Chandra, D., Singh, M. P., and Singh, R. M., 2000, Text Book of Coal, Tara Book Agency, India, pp. 200-203.
Chhatwal, G. R., 1997, Encyclopaedia of Environmental Analysis, Anmol publication, New Delhi, India, v. 2, pp. 735-811.

Coulsen, L. and Forbes, H., 1952, The Law of Water and land drainage. VI addition by Hobby Sweet and Maxwell ltd, London, $146 \mathrm{p}$.

ICMR, 1975, Guide line for drinking water quality, $186 \mathrm{p}$.

ISI, 1983, Guideline for drinking and irrigation water quality, $122 \mathrm{p}$. Liebman, 1962, Environmental Science, New Central Book Agency Pvt. Ltd, Kolkata, India, 212 p.

Rao, K. S., 1993, Practical Ecology. Anmol Publications Pvt. Ltd, pp. 22-57.

WHO, 1993, Guideline for Drinking water quality. v. 1 (2ed. Edition), Geneva, pp. 1-3 (e-copy). 